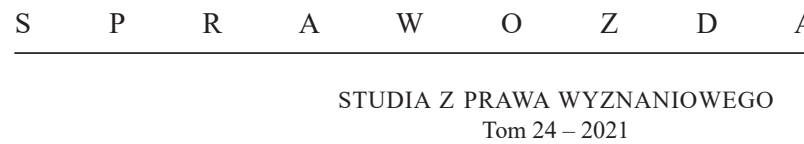

DOI: https://doi.org/10.31743/spw.12802

KATARZYNA PLUTA*

\title{
IV OGÓLNOPOLSKI STUDENCKI KONKURS WIEDZY Z ZAKRESU PRAWA WYZNANIOWEGO, OPOLE, 9 KWIETNIA $2021 \mathrm{R}$.
}

IV National Law on Religion Contest for Students, Opole, 9 April 2021

Ograniczenia pandemii nie ograniczyły aktywności studentów. Dnia 9 kwietnia 2021 r. tym razem wyjątkowo, bo przez łącza internetowe, odbył się IV Ogólnopolski Studencki Konkurs Wiedzy z Zakresu Prawa Wyznaniowego. Zwyczajowo konkurs odbywa się na Wydziale Prawa i Administracji Uniwersytetu Opolskiego w pierwszy piątek grudnia. Jednak obecna sytuacja epidemiczna spowodowała jego przesunięcie, co nie zniechęciło organizatorów ani uczestników do podjęcia trudu przygotowań. Edycja „koronawirusowa” nie mogła odbyć się pod innym hasłem, jak tylko Ograniczenia wolności sumienia i religii.

Organizatorami konkursu były: Polskie Towarzystwo Prawa Wyznaniowego oraz Katedra Nauk o Państwie i Prawie Instytutu Nauk Prawnych Uniwersytetu Opolskiego. Ze względu na wciąż przedłużane ograniczenia pierwszy etap tej edycji przybrał postać rozprawki pt. Konstytucyjność ograniczeń wolności sumienia i religii w zwiąku z pandemia COVID-19, zaś finał, w formie ustnej, odbył się z wykorzystaniem platformy Teams. Uroczystego otwarcia części finałowej dokonali dr hab. Marek Bielecki, prof. ASzWoj - Prezes Polskiego Towarzystwa Prawa Wyznaniowego oraz dr hab. Paweł Sobczyk, prof. UO - Dziekan Wydziału Prawa i Administracji Uniwersytetu Opolskiego.

* Mgr, Katedra Nauk o Państwie i Prawie, Wydział Prawa i Administracji, Uniwersytet Opolski, ul. Katowicka 87a, 45-067 Opole, e-mail: kpluta@uni.opole.pl. ORCID 0000-0001-6899-1574. 
Konkurs skierowany był do studentów studiów pierwszego i drugiego stopnia oraz jednolitych studiów magisterskich studiujących na jednej z działających w Polsce szkół wyższych. Do konkursu zgłosiło się czternaścioro uczestników, reprezentujących m.in. Uniwersytet Jagielloński, Uniwersytet Warmińsko-Mazurski w Olsztynie, Uniwersytet Kardynała Stefana Wyszyńskiego w Warszawie - Wydział Prawa Kanonicznego oraz Wydział Prawa i Administracji czy Uniwersytet Opolski.

W zmaganiach konkursowych pierwsze miejsce zajął Igor Mędela z Uniwersytetu Jagiellońskiego, który w poprzednich dwóch edycjach zajmował drugie miejsce. $\mathrm{W}$ tej edycji, dzięki wytrwałym przygotowaniom, udało mu się wskoczyć o stopień wyżej.

Kolejne miejsca należały już do studentów z Wydziału Prawa i Administracji Uniwersytetu Opolskiego. I tak drugie miejsce zajął Bartłomiej Biernacki, trzecie Krzysztof Górecki, czwarte Jakub Krzykawski. Do finału zakwalifikowała się również studentka WPiA UO Katarzyna Makłowicz. Cała czwórka trenowała pod okiem mgr Katarzyny Pluty. Sukces jest tym większy, gdyż to pierwszy raz od początku istnienia konkursu, kiedy reprezentanci Uniwersytetu Opolskiego stają na podium.

Laureaci otrzymali cenne nagrody rzeczowe, zaś wszyscy uczestnicy konkursu drobne upominki i certyfikaty uczestnictwa. Niestety, ograniczenia wprowadzane z powodu COVID-19 uniemożliwiły wspólne spotkanie i spędzenie czasu w Opolu, który zawsze był okazją do pogłębienia wiedzy z prawa wyznaniowego oraz wzajemnej wymiany poglądów, a także rozwijania u studentów umiejętności rozwiązywania problemów z zakresu prawa wyznaniowego i szerzenia świadomości prawnej oraz integracji środowisk akademickich. Mimo to, chociaż zdalnie, udało się nawiązać nowe znajomości i zaplanować wspólne projekty związane z upowszechnianiem wiedzy z zakresu prawa wyznaniowego i zaprosić wszystkich zainteresowanych na piątą edycję konkursu, którą zaplanowano na grudzień $2021 \mathrm{r}$. 